\title{
A Comparative Analysis of Job Stress of Field Managers and Workers in Korean Construction Projects
}

\author{
Zhen Zhang, Woo-Hwan Lee, Young-Wha Choi, Sung-Hoon $\mathrm{An}^{*}$ \\ Department of Architectural Engineering, Daegu University, Gyeongsan-Si, South Korea. \\ *Corresponding author: Email: shan@daegu.ac.kr
}

Received June $26^{\text {th }}, 2013$; revised August $12^{\text {th }}, 2013$; accepted August $22^{\text {nd }}, 2013$

Copyright (C) 2013 Zhen Zhang et al. This is an open access article distributed under the Creative Commons Attribution License, which permits unrestricted use, distribution, and reproduction in any medium, provided the original work is properly cited.

\begin{abstract}
A successful construction project hinges on the effective and efficient management of human resources. The stress of human resources is directly related with work performance, and as such, should be managed to improve work performance. This study aims to perform a comparative analysis of job stress levels after a survey on the job stress of field managers and workers. Through the analysis, it is found that the stress levels of field managers are different from those of the workers and construction field managers and workers get job stress scores less than average scores of Korean male workers. In addition, different personal factors affect the field managers and the workers differently. Therefore, understanding by which factor the other parties become stressed is expected to improve efficiency in the management of human resources.
\end{abstract}

Keywords: Job Stress; Comparison; Field Manager; Worker; Korea

\section{Introduction}

Every construction project involves the participation of many different people. For this reason, the success of a construction project relies heavily on how efficiently and effectively the human resources (manpower) are managed $[1,2]$. For the successful completion of a construction project, the human resources must be provided with an environment in which they can engage in their tasks faithfully [3]. Stress can have either positive or negative effects. That is, if the stress level is appropriate, it will help give the human resources a positive tension, improving their work efficiency as a result, while if the stress level is too high, it will have an adverse influence on the work efficiency and capability of the human resources $[4,5]$. In particular, as the stress level of the human resources has a close relation with safety accidents, it should be managed in order to reduce safety accidents $[6,7]$.

Many studies have been conducted on stress management for human resources [4-14]. The previous studies were conducted either on field managers or on individual workers. However, the stress level of field managers can be different from that of workers, even in the same construction site. If the stress influencing factors are understood by the participants (field managers or worker), it is expected that human resources will be effectively managed, and the stress level can be lessened through efforts to relieve the other's stress.

Therefore, the goal of this study is to perform a comparative analysis after a survey of the job stress of field managers and workers in Korean construction sites.

\section{Job Stress}

It is difficult to find a clear-cut definition of the term "job stress" in the literature. Sun [15] defined job stress as "a physical and emotional phenomenon experienced in various working situations, when workers are at risk, when they have a conflict with their boss or colleagues, when they feel emotional affliction arising out of a discrepancy between their aptitude and their job, when their ability is not recognized or they feel they lack ability, or when they are in charge of an important or extremely difficult job." In short, one can experience job stress when one is not given a working environment in which one can control the job, or with which one's motivation or capability is compatible.

If one is under job stress continuously and the stress has been accumulated without being released, one can experience a deterioration in one's physical condition or family discord, frequent absences from work or frequent 
job changes, high emotional disturbance and maladjustment, and low performance [11,12]. Therefore, job stress is one of the main factors that have an influence on the organizational performance.

\section{Research Method}

The scope of this research was limited to field managers and workers working on Korean construction sites of the top 30 Korea construction companies, because the job stress of human resources can be different depending on the company size (large or small). More specifically, the working environment (including working condition and remuneration), which are depending on the company size, can affect stress level differently. In addition, the subjects studied in this research, both field managers and workers, were limited to men only, since the field managers and workers in the construction site are usually men.

To compare job stress between field managers and workers, the method of measuring job stress was first selected. Job stress was measured through questionnaires. The questions on the questionnaire were selected and considered to be most appropriate for this study after reviewing the questions used in the previous studies. The data was collected from February through May, 2013.

The job stress of field managers and workers can be measured through the stress influencing factors. There are many research papers that mention different methods of measuring job stress through stress influencing factors [4-14]. We used the "Occupational Stress Scale for Korean Employees" developed by the Korea Occupational Safety and Health Agency (KOSHA) to measure the occupational stress of the field managers of construction projects [16], because the "Occupational Stress Scale for Korean Employees" was developed by the research team of KOSHA after reviewing many occupational stress instruments, it is appropriate for Korean workers, and its validity has been verified through many cases.

There are two versions of the "Occupational Stress Scale for Korean Employees": the basic version (43 questions) and the shortened version (24 questions). The shortened version with 24 questions was employed in this study, since the basic version has so many questions that it can be difficult for respondents to complete.

The shortened version consists of 24 questions in 7 categories (job demand, job control, interpersonal conflict, job instability, organizational system, inappropriate compensation, and organizational climate). The details of 24 questions are expressed in Table 1 [16].

\section{Comparative Analysis of Job Stress}

\subsection{Reliability and Validity of Variables}

To measure the job stress in 7 categories, the question- naire was comprised of different questions. Therefore, the reliability must be analyzed using Chronbach's Alpha to verify the consistency of the questions in each category, and to perform a factor analysis to determine whether the questions are appropriate.

However, the reliability and validity were not verified in this study, because the occupational stress scale used in this study had already been verified in a previous study [16]. In addition, the questions should be identical to compare the job stress measured in this study with Korea standard occupational stress.

\subsection{A Comparative Analysis of Job Stress}

The job stress of field managers and workers in construction projects was measured through a survey. As mentioned earlier, the abridged version of the "Occupational Stress Scale for Korean Employees" developed by KOSHA was used in this study. The survey results were scored by category using Equation (1) [16]. If the job stress scores are lower, the workers are less stressed.

$$
\frac{(\text { sum of score-number of question })}{(\text { highest score-number of question })} \times 100
$$

The job stress scores of field managers and workers shown in Table 2 were compared with the average job stress scores of Korean men announced by KOSHA. As indicated in Table 3, the job stress score of field managers was shown to be considerably lower than the average, while the job stress score of workers was shown to be slightly lower than the average.

Table 3 shows the results of a t-test to statistically verify the job stress scores between the field managers and workers. Through the t-test results, it was revealed that work stress scores were statistically different in all of the 7 categories, at a 95\% confidence level $(p<0.05)$.

As shown in Table 2, the job stress scores of field managers are remarkably different from those of workers, which showed an entirely different tendency. Therefore, it is revealed that the factors that have an influence on the job stress of field managers are believed to be different from those that affect the worker's stress, and it is verified by T-test as shown in Table 3.

\subsection{Review of the Comparison Results of Job Stress}

In terms of job demand, the score of the field mangers was similar to the average, while the score of the workers was considerably lower than the average. This may be because the construction workers do not receive much stress from the workload they carry and the rest they take.

In terms of job control, the score of field managers was shown to be considerably lower, while that of workers 
Table 1. Details of the shortened version with 24 questions.

\begin{tabular}{|c|c|}
\hline Categories & Questions \\
\hline Job demand & $\begin{array}{l}\text { I am always under pressure to meet my deadlines due to the heavy workload. } \\
\text { The workload has been significantly increased. } \\
\text { I can get sufficient rest during work. } \\
\text { I have to deal with a couple of jobs at the same time. }\end{array}$ \\
\hline Job control & $\begin{array}{l}\text { I need to be creative to perform my job. } \\
\text { I need a high level of skill and knowledge to perform my job. } \\
\text { I am empowered to determine the working time and job performance, and I can make a decision at my discretion. } \\
\text { I can determine my workload and change my work schedule at my discretion. }\end{array}$ \\
\hline Interpersonal conflict & $\begin{array}{l}\text { I can get some help from my boss to finish my work. } \\
\text { I can get some help from my colleagues to finish my work. } \\
\text { There are people at work who can understand me and my situation whenever I have difficulty with my job. }\end{array}$ \\
\hline Job instability & $\begin{array}{l}\text { Our company is unstable, and the future of my job is insecure. } \\
\text { There was an undesirable change in my working condition (e.g. layoff) or I expect such a change. }\end{array}$ \\
\hline Organizational system & $\begin{array}{l}\text { Our company has a good supporting system including staff, space, facility and training if necessary. } \\
\text { Our company has an efficient system that enables cooperation between departments without conflict. } \\
\text { I can find an opportunity and path to reflect my ideas. }\end{array}$ \\
\hline $\begin{array}{l}\text { Inappropriate compensa- } \\
\text { tion }\end{array}$ & $\begin{array}{l}\text { Considering my efforts and performance, my remuneration is appropriate. } \\
\text { Considering that my situation is expected to become more favorable, I do my job without feeling burdened. } \\
\text { I am given opportunities to develop and show my ability. }\end{array}$ \\
\hline Organizational climate & $\begin{array}{l}\text { I feel uneasy at office dinners. } \\
\text { I am given work instructions with no consistent criteria. } \\
\text { The working atmosphere is authoritative and vertical. } \\
\text { I get discriminated against sexually. }\end{array}$ \\
\hline
\end{tabular}

Table 2. Comparison of job stress with Korean workers’ standard.

\begin{tabular}{|c|c|c|c|c|c|c|}
\hline Element & $\begin{array}{c}\text { Korean workers' } \\
\text { standard } \\
\text { (A) }\end{array}$ & $\begin{array}{l}\text { Field managers } \\
\text { (B) }\end{array}$ & $\begin{array}{l}\text { Workers } \\
\text { (C) }\end{array}$ & $\mathrm{B}-\mathrm{A}$ & $\mathrm{C}-\mathrm{A}$ & $\mathrm{B}-\mathrm{C}$ \\
\hline Job demand & 52.40 & 54.38 & 46.12 & 1.98 & -6.28 & 8.26 \\
\hline Job control & 53.70 & 38.59 & 57.19 & -15.11 & 3.49 & -18.6 \\
\hline Interpersonal conflict & 41.20 & 32.07 & 40.19 & -9.13 & -1.01 & -8.12 \\
\hline Organizational system & 52.78 & 43.33 & 49.11 & -9.45 & -3.67 & -5.78 \\
\hline Inappropriate compensation & 52.11 & 41.75 & 48.96 & -10.36 & -3.15 & -7.21 \\
\hline Organizational climate & 40.95 & 35.44 & 42.48 & -5.51 & 1.53 & -7.04 \\
\hline Average & 49.03 & 40.85 & 47.24 & -8.18 & -1.79 & -6.39 \\
\hline
\end{tabular}

Table 3. Result of T-test for job stress.

\begin{tabular}{|c|c|c|c|c|c|c|}
\hline \multirow{2}{*}{ Type } & \multicolumn{2}{|c|}{ Field managers $(\mathrm{N}=99)$} & \multicolumn{2}{|c|}{ Workers $(\mathrm{N}=96)$} & \multirow{2}{*}{ T-value } & \multirow{2}{*}{ p-value } \\
\hline & Mean & S.d & Mean & S.d & & \\
\hline Job demand & 54.38 & 16.622 & 46.12 & 9.985 & 4.222 & 0.000 \\
\hline Job control & 38.59 & 14.007 & 57.19 & 12.163 & -9.884 & 0.000 \\
\hline Interpersonal conflict & 32.07 & 15.400 & 40.19 & 14.463 & -3.795 & 0.000 \\
\hline Job instability & 40.53 & 20.678 & 46.75 & 15.416 & -2.384 & 0.018 \\
\hline Organizational system & 43.33 & 12.447 & 49.11 & 8.366 & -3.816 & 0.000 \\
\hline Inappropriate compensation & 41.75 & 13.550 & 48.96 & 12.520 & -3.853 & 0.000 \\
\hline Organizational climate & 35.44 & 15.106 & 42.48 & 10.449 & -3.794 & 0.000 \\
\hline Average & 40.85 & 8.975 & 47.24 & 5.867 & -5.896 & 0.000 \\
\hline
\end{tabular}


was all shown to be slightly higher than the average. For the field mangers have high authority, and they can make the decision on working time and workload in their discretion; for this reason, they became less stressed.

In terms of interpersonal conflict, job instability, organizational system and inappropriate compensation, the scores of field managers and workers were shown to be lower than the average. In particular, the field managers were shown to become remarkably less stressed. It is supposed that the field managers surveyed in this study are the employees in the top 30 construction companies, and they are overall satisfied with their company.

In terms of organizational climate, the score of field managers was shown to be lower than the average. This is believed that people in an organization at construction site have a sense of friendship with each other.

\subsection{Job Stress Influencing Factors}

Based on the differences between field managers and workers in job stress scores, the job stress influencing factors were expected to be different. Therefore, to understand the respective job stress factors influencing either the field managers or the workers, as shown in Tables 4 and 5, t-test was conducted by marriage, hobby, and exercise and ANOVA was conducted by ageand character.

In terms of personal factors that have an impact on the job stress of the workers, as shown in Table 4, the older the field managers and workers are, the less stressed they become. In terms of job instability, the workers in their 20 s and 30s were less stressed compared to those in their $40 \mathrm{~s}$ and $50 \mathrm{~s}$. In terms of job demand, job instability and organizational system, the married workers were more stressed than those who were still single. In terms of inappropriate compensation, the workers who had a hobby were less stressed than those who did not have a hobby. In terms of job control, the workers who exercised regularly were less stressed than those who did not exercise regularly. Character was found to have an influence on the stress related with job demand and job control.

In terms of personal factors that can influence the job stress of field managers as shown in Table 5, the older the managers were, the more stressed they were regarding job instability. Married field managers were more stressed regarding job demand while less stressed regarding job control compared to the unmarried. In terms of inappropriate compensation, field managers with a hobby were less stressed than those who did not have a hobby. In terms of interpersonal conflict, the field managers who exercised regularly were less stressed than those who did not exercise regularly. Character was not shown to have an influence on the stress.

Through the analysis of the influence on stress levels of site managers and workers by personal factor (age, marriage, hobby, exercise and character), it was found that some personal factors had an impact on a specific stress. However, each personal factor had a different impact on the stress level of the workers from that of the field managers.

\section{Conclusions}

In this study, the job stress of field managers and workers in construction projects was measured. The results showed that the job stress of field managers was considerably lower than the average job stress of Korean men, while the job stress of the workers was slightly lower than the average. In addition, in the 7 categories of job stress, there were remarkable differences shown between the field managers and the workers. In particular, in terms of job control, the field managers became outstandingly less stressed compared with normal Korean men, because the field managers had high level of autonomy due to the nature of a construction project, and they can make a decision regarding working time and workload, which makes them less stressed. In addition, in terms of interpersonal conflict, job instability, organizational system, and inappropriate compensation, the scores of field managers were much lower than the average. One of these reasons is supposed that field managers are satisfied with their companies because they are employed by top 30 construction companies of Korea.

Through the analysis of personal factors (age, marriage, hobby, exercise, and character), a specific personal factor was found to have an impact on a particular category of job stress. However, the personal factors were found to differently affect the stress levels of field managers and the workers.

It is far-fetched to say that these research findings would bring the same results from all field managers and workers in construction projects because the field managers and the workers were limited to those employed by Korea's large construction companies. In addition, it is difficult to generalize the analysis results of the human resources. Therefore, it is necessary to study field managers and workers who work for small- and medium-sized construction companies in the future to determine whether these research findings are compatible.

If field managers and workers can understand the factors that cause stress to the other party, the human resources can be managed more effectively. This is expected to enable efficient management of the organization at construction sites and raise work performance.

\section{Acknowledgements}

This research was supported by Basic Science Research Program through the National Research Foundation of 
Table 4. Factors to effect the workers' job stress $(\mathrm{N}=96)$.

\begin{tabular}{|c|c|c|c|c|c|c|c|c|c|c|}
\hline \multicolumn{2}{|c|}{ Factor } & $\mathrm{N}$ & Job demand & Job control & $\begin{array}{l}\text { Interpersonal } \\
\text { conflict }\end{array}$ & $\begin{array}{c}\text { Job } \\
\text { instability }\end{array}$ & $\begin{array}{l}\text { Organizational } \\
\text { system }\end{array}$ & $\begin{array}{l}\text { Inappropriate } \\
\text { compensation }\end{array}$ & $\begin{array}{l}\text { Organizational } \\
\text { climate }\end{array}$ & Average \\
\hline \multirow{5}{*}{ Age } & $\sim 29$ & 4 & 45.35 & 67.20 & 50.00 & 40.63 & 54.70 & 60.40 & 43.80 & 51.73 \\
\hline & $30-39$ & 17 & 41.93 & 62.90 & 40.68 & 36.77 & 44.14 & 52.46 & 41.21 & 45.69 \\
\hline & $40-49$ & 40 & 47.84 & 56.74 & 41.26 & 48.44 & 48.78 & 46.87 & 44.09 & 47.70 \\
\hline & $50 \sim$ & 35 & 46.27 & 53.77 & 37.62 & 50.36 & 51.28 & 48.33 & 41.10 & 46.94 \\
\hline & \multicolumn{2}{|c|}{$\mathrm{p}$-value } & 0.241 & $0.023^{*}$ & 0.369 & $0.015^{*}$ & $0.015^{*}$ & 0.117 & 0.606 & 0.280 \\
\hline \multirow{3}{*}{ Marriage } & Yes & 82 & 47.43 & 56.66 & 40.65 & 48.93 & 49.87 & 48.47 & 42.48 & 47.77 \\
\hline & No & 14 & 38.41 & 60.27 & 37.49 & 33.93 & 44.66 & 51.79 & 42.44 & 44.13 \\
\hline & \multicolumn{2}{|c|}{$\mathrm{p}$-value } & $0.001^{*}$ & 0.305 & 0.604 & $0.001^{*}$ & $0.030^{*}$ & 0.362 & 0.989 & 0.164 \\
\hline \multirow{3}{*}{ Hobby } & Yes & 80 & 45.89 & 56.98 & 40.42 & 46.25 & 49.32 & 47.60 & 42.53 & 46.98 \\
\hline & No & 16 & 47.29 & 58.23 & 39.06 & 49.22 & 48.08 & 55.73 & 42.22 & 48.53 \\
\hline & \multicolumn{2}{|c|}{ p-value } & 0.611 & 0.708 & 0.734 & 0.485 & 0.589 & $0.017^{*}$ & 0.914 & 0.337 \\
\hline \multirow{3}{*}{ Exercise } & Yes & 63 & 47.25 & 54.89 & 39.55 & 44.84 & 48.34 & 47.22 & 43.68 & 46.52 \\
\hline & No & 33 & 43.96 & 61.57 & 41.42 & 50.38 & 50.59 & 52.27 & 40.18 & 48.61 \\
\hline & \multicolumn{2}{|c|}{ p-value } & 0.088 & $0.004^{*}$ & 0.506 & 0.064 & 0.212 & 0.060 & 0.120 & 0.053 \\
\hline \multirow{5}{*}{ Character } & leading & 8 & 32.05 & 68.76 & 38.55 & 40.63 & 42.98 & 56.25 & 45.34 & 46.36 \\
\hline & prudent & 36 & 46.03 & 55.41 & 39.82 & 44.79 & 50.20 & 46.75 & 42.04 & 46.41 \\
\hline & stable & 42 & 48.69 & 56.42 & 40.67 & 47.92 & 48.98 & 49.41 & 43.19 & 47.88 \\
\hline & social & 10 & 46.89 & 57.53 & 40.83 & 53.75 & 50.66 & 49.17 & 38.77 & 48.21 \\
\hline & \multicolumn{2}{|c|}{ p-value } & $0.000^{*}$ & $0.039^{*}$ & 0.979 & 0.248 & 0.153 & 0.276 & 0.556 & 0.650 \\
\hline
\end{tabular}

*Gap is significant at the 0.05 level (2-tailed).

Table 5. Factors to effect the field managers' job stress $(\mathrm{N}=99)$.

\begin{tabular}{|c|c|c|c|c|c|c|c|c|c|c|}
\hline \multicolumn{2}{|c|}{ Factor } & $\mathrm{N}$ & Job demand & Job control & $\begin{array}{l}\text { Interpersonal } \\
\text { conflict }\end{array}$ & $\begin{array}{c}\text { Job } \\
\text { instability }\end{array}$ & $\begin{array}{c}\text { Organizational } \\
\text { system }\end{array}$ & $\begin{array}{l}\text { Inappropriate } \\
\text { compensation }\end{array}$ & $\begin{array}{l}\text { Organiza- } \\
\text { tional climate }\end{array}$ & Average \\
\hline \multirow{4}{*}{ Age } & $\sim 29$ & 5 & 36.28 & 37.52 & 21.66 & 20.00 & 32.50 & 31.66 & 18.76 & 28.32 \\
\hline & $30-39$ & 62 & 56.48 & 40.04 & 33.47 & 37.90 & 43.17 & 43.01 & 35.71 & 41.38 \\
\hline & $40-49$ & 30 & 53.36 & 36.69 & 31.94 & 47.92 & 45.65 & 41.12 & 37.32 & 41.98 \\
\hline & $50 \sim$ & 2 & 50.00 & 25.05 & 16.65 & 62.50 & 40.65 & 37.50 & 40.65 & 39.00 \\
\hline \multirow{3}{*}{ Marriage } & Yes & 63 & 57.37 & 35.74 & 32.80 & 42.86 & 43.58 & 40.88 & 34.74 & 41.12 \\
\hline & No & 36 & 49.16 & 43.59 & 30.78 & 36.46 & 42.90 & 43.28 & 36.65 & 40.39 \\
\hline & \multicolumn{2}{|c|}{ p-value } & $0.017^{*}$ & $0.007^{*}$ & 0.533 & 0.139 & 0.794 & 0.398 & 0.548 & 0.697 \\
\hline \multirow[b]{2}{*}{ Hobby } & Yes & 83 & 55.00 & 37.52 & 31.02 & 40.21 & 42.72 & 40.56 & 35.42 & 40.33 \\
\hline & No & 16 & 51.19 & 44.16 & 37.50 & 42.19 & 46.51 & 47.93 & 35.56 & 43.56 \\
\hline \multirow{3}{*}{ Exercise } & Yes & 66 & 53.91 & 37.90 & 29.16 & 37.69 & 42.74 & 39.90 & 34.58 & 39.39 \\
\hline & No & 33 & 55.33 & 39.97 & 37.88 & 46.21 & 44.53 & 45.45 & 37.15 & 43.77 \\
\hline & \multicolumn{2}{|c|}{ p-value } & 0.690 & 0.491 & $0.015^{*}$ & 0.053 & 0.501 & 0.054 & 0.428 & $0.021^{*}$ \\
\hline \multirow{5}{*}{ Character } & leading & 9 & 50.02 & 31.27 & 37.96 & 40.28 & 44.47 & 40.74 & 30.58 & 39.30 \\
\hline & prudent & 36 & 57.14 & 40.47 & 33.09 & 42.71 & 41.84 & 41.90 & 38.04 & 42.16 \\
\hline & stable & 38 & 52.00 & 38.18 & 29.38 & 38.82 & 43.12 & 41.89 & 35.22 & 39.78 \\
\hline & social & 16 & 56.28 & 39.47 & 32.82 & 39.84 & 46.51 & 41.66 & 32.84 & 41.33 \\
\hline & \multicolumn{2}{|c|}{ p-value } & 0.463 & 0.365 & 0.451 & 0.882 & 0.659 & 0.996 & 0.485 & 0.661 \\
\hline
\end{tabular}

*Gap is significant at the 0.05 level (2-tailed). 
Korea (NRF) funded by the Ministry of Education, Science and Technology (2011-0021835).

\section{REFERENCES}

[1] S.-H. An, "A Study on the Construction Manager's Leadership Styles Based on Condition of Building Projects," Journal of the Architectural Institute of Korea, Vol. 25, No. 4, 2009, pp. 231-238.

[2] D. Lee, M. Kim and S. Kim, "Management Performance Evaluation Model of Korean Construction Firms," Journal of Building Construction and Planning Research, Vol. 1, No. 2, 2013, pp. 27-38. doi:10.4236/jbcpr.2013.12005

[3] N. Inyang, M. Al-Hussein, M. El-Rich and S. Al-Jibouri, "Ergonomic Analysis and the Need for Its Integration for Planning and Assessing Construction Tasks," Journal of Construction Engineering and Management, Vol. 138, No. 12, 2012, pp. 1370-1376. doi:10.1061/(ASCE)CO.1943-7862.0000556

[4] M.-Y. Leung, I. Y. S. Chan and P. Olomolaiye, "Impact of Stress on the Performance of Construction Project Managers," Journal of Construction Engineering and Management, Vol. 134, No. 8, 2008, pp. 644-652.

[5] M.-Y. Leung, I. Y. S. Chan and C. Dongyu, "Structural Linear Relationships between Job Stress, Burnout, Physiological Stress, and Performance of Construction Project Managers," Engineering, Construction and Architectural Management, Vol. 18, No. 3, 2011, pp. 312328. doi:10.1108/09699981111126205

[6] M.-Y. Leung, I. Y. S. Chan and J. Yu, "Preventing Construction Worker Injury Incidents through the Management of Personal Stress and Organizational Stressors," Accident Analysis \& Prevention, Vol. 48, 2012, pp. 156166. doi:10.1016/j.aap.2011.03.017

[7] O. O. Abbe, C. M. Harvey, L. H. Ikuma and F. Aghazadeh, "Modeling the Relationship between Occupational Stressors, Psychosocial/Physical Symptoms and Injuries in the Construction Industry," International Journal on Industrial Ergonomics, Vol. 41, No. 2, 2011, pp. 106-117.

\section{doi:10.1016/j.ergon.2010.12.002}

[8] H.-J. Choi and H.-G. Kwon, "The Stress Influences on the Job Attitudes toward the Employees of Construction Industries," Korean Journal of Business Administration, Vol. 21, No. 4, 2008, pp. 1723-1749.

[9] J.-H. Eom, "A Study on the Stress Control of Construction Workers," Master Thesis, Seoul National University of Technology, Seoul, 2003.

[10] M.-Y. Leung, I. Y. S. Chan and J. Yu, "Integrated Model for the Stressors and Stresses of Construction Project Managers in Hong Kong," Journal of Construction Engineering and Management, Vol. 135, No. 2, 2009, pp. 126-134. doi:10.1061/(ASCE)0733-9364(2009)135:2(126)

[11] P. Bowen, P. Edwards and H. Lingard, "Workplace Stress Experienced by Construction Professionals in South Africa," Journal of Construction Engineering and Management, Vol. 139, No. 4, 2013, pp. 393-403. doi:10.1061/(ASCE)CO.1943-7862.0000625

[12] P. E. D. Love, D. J. Edwards and Z. Irani, "Work Stress, Support, and Mental Health in Construction," Journal of Construction Engineering and Management, Vol. 136, No. 6, 2010, pp. 650-658. doi:10.1061/(ASCE)CO.1943-7862.0000165

[13] S.-H. An, Z. Zhang and U.-K. Lee, "Correlation between Job Stress and Job Satisfactionof Building Construction Field Managers," Journal of the Korea Institute of Building Construction, in Press, 2013.

[14] T.-H. Jeong, "The Study of an Analysis on Job Stress of Affecting Safety and Management Performance for Workers in the Construction Industry," Ph.D. Thesis, Chosun University, Gwangju, 2009.

[15] J.-W. Sun, B.-S. Oh, D.-S. Hwang and J.-Y. Kim, “An Introduction to Job Stress," Korean Studies Information, Paju, 2010.

[16] J.-W. Sun, B.-S. Oh, D.-S. Hwang and J.-Y. Kim, "A Measurement of Job Stress," Korean Studies Information, Paju, 2010. 